\title{
PENGARUH KONSEP ACCELERATED TEACHING MODEL MASTER TERHADAP HASIL BELAJAR FISIKA SISWA DI MAN 2 MODEL MEDAN
}

\author{
Yul Ifda Tanjung \\ Prodi Pendidikan Fisika Unimed \\ yulifda84@gmail.com
}

\begin{abstract}
Abstrak
Salah satu faktor yang dapat mendukung keberhasilan kegiatan pembelajaran adalah penggunaan model pembelajaran bervariasi sesuai dengan tujuan yang ingin dicapai. Konsep Accelerated Teaching model MASTER merupakan salah satu model pembelajaran yang mengajarkan siswa memahami bagaimana cara belajar dan cara berpikir dengan penerapan langkah MASTER. Oleh karena itu, penelitian ini dilakukan untuk mengetahui ada atau tidaknya pengaruh konsep Accelerated Teaching model MASTER terhadap hasil belajar siswa di MAN 2 MODEL Medan pada materi pokok listrik dinamis dengan jenis penelitian quasi eksperimen menggunakan instrumen penelitian tes pilihan berganda. Sampel diambil dari dua kelas yang homogen sebagai kelas eksperimen dan kelas kontrol. Kelas eksperimen diber perlakuan pembelajaran dengan model MASTER dan kelas kontrol diberi perlakuan pembelajaran yang biasa dilakukan oleh guru. Berdasarkan penelitian, rata-rata nilai postes dari kelas eksperimen lebih tinggi dari kelas kontrol dan setelah dilakukan pengujian hipotesis uji t diperoleh kesimpulan bahwa ada pengaruh konsep Accelerated Teaching model MASTER terhadap hasil belajar siswa pada materi pokok listrik dinamis di MAN 2 Model Medan. Dengan melihat keberhasilan pembelajaran, maka disarankan untuk aplikasi model pembelajaran MASTER dalm pembelajaran fisika yang lain.

Kata Kunci : Konsep Accelerated Teaching, hasil belajar fisika
\end{abstract}

\section{PENDAHULUAN}

Saat ini informasi melalui berbagai media seperti televisi, majalah, surat kabar, radio, seminar, ensiklopedia, buku elektronik atau e-book, dan internet dapat dengan muda diperoleh. Informasi yang tersedia jauh lebih banyak dari yang dibutuhkan. Namun, tidak semua informasi memberikan nilai yang positif. Hal ini seharusnya menjadi pemikiran bagi dunia pendidikan untuk dapat meninjau kembali peran dan cara guru mengajar di kelas.

Selama ini guru dipandang sebagai sumber informasi utama, namun karena sedemikian mudahnya siswa mendapatkan informasi maka guru seharusnya tanggap dan menyesuaikan diri terhadap perkembangan tersebut.
Salah satu yang dapat dilakukan adalah menerapkan peran guru sebagai fasilitator dan katalisator. Hal ini sesuai dengan pernyataan Gunawan (2006:165) "Agar guru dapat mengikuti perkembangan zaman, guru harus dapat menjadi fasilitator dan katalisator dalam proses pembelajaran".

Dalam proses pembelajaran apabila guru dapat menerapkan kedua peran tersebut maka segala kegiatan dalam pembelajaran akan terasa lebih menyenangkan dan lebih bermakna bagi siswa. Hal ini seharusnya juga berlaku untuk mata pelajaran Fisika, namun kenyataannya dari hasil pengalaman penulis ketika melaksanakan PPL-T di SMP Negeri 1 Tanjung Morawa selama tiga bulan pada tahun 2006 banyak siswa 
mengatakan bahwa pelajaran Fisika itu sulit dimengerti dan penerapan rumusrumus ke dalam bentuk soal juga tidak mudah. Selain itu, belajar Fisika terasa membosankan dan tidak menarik karena hanya konsep, teori lalu contoh sial dan tidak ada praktek serta aplikasi dalam kehidupan sehari-hari.

Masalah ini sejalan dengan hasil wawancara penulis dengan guru Fisika di MAN 2 Model Medan yaitu Hanim (2007) yang menyatakan bahwa meskipun telah memiliki sarana pembelajaran Fisika lengkap tetap saja kebanyakan dari siswa-siswa kelas $\mathrm{X}$ di sekolah tersebut lebih menyukai pelajaran Biologi atau Kimia dibandingkan pelajarna Fisika. Hal ini terlihat dari nilai rata-rata mata pelajaran Fisika untuk kelas X MAN 2 Model T.P. 2006/2007 adalah 70,15. Sedangkan mata pelajaran IPA lainnya yaitu Biologi dan Kimia masing-masing memperoleh nilai 78,15 dan 74,75 .

Menyadari hal tersebut, perlu adanya suatu pembaharuan dalam pembelajaran yang memungkinkan siswa untuk dapat mempelajari Fisika lebih mudah, lebih cepat, lebih bermakna, efektif dan menyenangkan. Dasar dari penerapan Accelerated Teaching adalah konsep Accelerated Learning. Menurut Rose dan Nicholl (2002:37) : "Accelerated Learning berusaha memadukan aneka permainan dan aktivitas, emosi dan musik, relaksasi, visualisasi, permainan peran, warna, peta konsep, cara berpiki positif dan suasana emosional yang menyenangkan sehingga kegiatan pembelajaran menjadi lebih bermakna dengan daya ingat yang lebih kuat".

Dalam konsep Accelerated Teaching, siswa diajarkan untuk memahami "bagaimana cara belajar" dan "bagaimana cara berpikir" dengan menerapkan enam langkah dasar yang dikenal dengan istilah MASTER yang merupakan singkatan dari kata Mind (pikiran), Acquire the facts (memperoleh informasi), search out the meaning (menyelidiki makna), Trigger the memory (memicu ingatan), exhibit what you know (memamerkan apa yang diketahui), reflect (merefleksikan).

Model ini diyakini dapat memberikan pengaruh bagi perkembangan dan hasil belajar fisika yang diperoleh siswa. Sebagaimana yang dikemukakan oleh Milward dalam Rose dan Nicholl (2002:354) : "Model 6 langkah terbukti telah menjadi kerangka acuan tidak ternilai untuk meningkatkan kecepatan serta motivasi baik para guru maupun siswa berkenaan dengan spektrum topik yang luas, termasuk meningkatkan prestasi ujian siswa dan memahami bagaimana siswa belajar di kelas"

Oleh karena itu, penulis tertarik untuk melakukan penelitian di MAN Model Medan dengan menerapkan konsep Accelerated Teaching menggunakan model MASTER agar dapat meningkatkan hasil belajar fisika siswa. MAN 2 Model mempunyai sarana pembelajaran yang lengkap seperti buku pelajaran, buku bacaan, fasilitas laboratorium sekolah, dan berbagai media pengajaran. Lengkapnya sarana pembelajaran dapat mendukung penerapan Accelerated Teaching dengan model MASTER agar berlangsung secara maksimal dan sesuai apa yang diharapkan.

\section{METODE PENELITIAN}

Metode penelitian yang digunakan adalah quasi eksperimen (eksperimen semu) dengan desain penelitian two group pretest postest design yang melibatkan dua kelas yaitu kelas eksperimen diberi perlakuan pembelajaran model MASTER dan kelas kontrol diberi perlakuan pembelajaran konvensional. Sebagai sampel penelitian adalah siswa kelas $\mathrm{X}_{6}$ (kelas eksperimen) dan siswa kelas $\mathrm{X}_{7}$ (kelas kontrol) semester II MAN 2 Model Medan yang dipilih dengan teknik cluster random sampling berjumlah masing-masing 30 orang siswa. Adapun tahap-tahap teknik 


$\begin{array}{llrl}\text { pelaksanaan } & \text { penelitian } & \text { adalah } & \text { terhadap hasil belajar fisika siswa di } \\ \text { melaksanakan } & \text { pretes pada kelas } & \text { MAN 2 Model Medan. }\end{array}$
eksperimen dan kelas kontrol untuk mengetahui hasil belajar siswa sebelum diberi perlakuan, melakukan analisa data pretes yaitu uji normalitas dan uji homogenitas, pemberian perlakuan model MASTER pada kelas eksperimen dan pemberian perlakuan model konvensional pada kelas kontrol, melaksanakan postes untuk mengetahui kemampuan akhir siswa pada kelas eksperimen dan kelas kontrol, tahap terakhir melakukan analisa data postes yaitu uji normalitas, uji homogenitas dan uji t pada kelas eksperimen dan kelas kontrol. Dari uji hipotesis diketahui ada atau tidaknya pengaruh model MASTER terhadap hasil belajar siswa.

\section{HASIL PENELITIAN DAN PEMBAHASAN}

Pada awal penelitian, kedua kelas diberikan pretes yang bertujuan mengetahui kemampuan awal belajar siswa. Dari nilai pretes diperoleh bahwa kemampuan awal siswa pada kedua kelas sama yaitu 40,26 pada kelas eksperimen dan 40,13 pada kelas kontrol. Selanjutnya diterapkan model pembelajaran yang berbeda dan diperoleh nilai postes kelas eksperimen 74,53 dan kelas kontrol 68,67. Hasil ini menunjukkan bahwa nilai rata-rata kelas eksperimen yang diberi perlakuan pembelajaran model MASTER lebih tinggi dibandingkan kelas kontrol dengan perlakuan pembelajaran Konvensional. Berdasarkan uji normalitas dan homogenitas terhadap data pretes dan postes dapat disimpulkan bahwa data penelitian telah memenuhi uji persyaratan untuk dilakukan pengujian hipotesis penelitian. Dari hasil pengujian hipotesis pada data postes diperoleh $t_{\text {hitung }}>t_{\text {tabel }}$ berarti $\mathrm{H}_{\mathrm{a}}$ diterima dan $\mathrm{H}_{0}$ ditolak, sehingga dapat disimpulkan bahwa ada pengaruh konsep Accelerated Teaching model MASTER
Konsep Accelerated Teaching model MASTER memberikan pengaruh pada kelas eksperimen karena rancangan model MASTER yang diterapkan peneliti mampu mengatur tahapan kegiatan pembelajaran dengan penggunaan senam otak, musik, VCD pembelajaran fisika dan alat-alat percobaan listrik dinamis, peta pikiran dan media pembelajaran lain sehingga membantu peneliti untuk membangun ketertarikan dan keaktifan siswa terhadap materi listrik dinamis.

Penerapan langkah MASTER dan pengaruhnya selama penelitian diuraikan sebagai berikut :

1. Pada tahapan Mind siswa diarahkan untuk menenangkan pikiran dan menemukan manfaat dari pembelajaran materi pokok listrik dinamis. Hasil pengamatan peneliti menunjukkan siswa terlihat bersemangat dan tertarik karena adanya kegiatan senam otak yang diiringi musik. Namun, kegiatan senam otak yang dilakukan peneliti hanya bersifat umum dan terpisah dari materi pelajaran. Oleh karena itu, disarankan kepada peneliti selanjutnya untuk mengaitkan setiap langkah kegiatan senam otak dengan materi pelajaran yang akan dipelajari siswa.

2. Tahapan Acquire the facts memberikan kesempatan bagi siswa untuk memperoleh informasi listrik dinamis menggunakan teknik belajar VAK. Pada tahapan ini, siswa mengumpulkan semua bahan materi listrik dinamis untuk dipahami dan diterapkan pada tahapan selanjutnya. Dari hasil pengamatan peneliti, siswa memberikan respon yang baik karena peneliti menggunakan VCD pembelajaran Fisika, peta pikiran dan demonstrasi alat-alat percobaan listrik dinamis. Hal ini terlihat dari antusias siswa dalam mengajukan pertanyaan 
seputar materi yang diajarkan setelah mereka memperoleh informasi. Namun, pada tahapan ini peneliti menemukan kendala yaitu kurangnya sumber pelajaran (tidak ada buku panduan) yang digunakan siswa sehingga siswa hanya mengharapkan informasi yang disediakan peneliti. Hal ini membuat peneliti kesulitan untuk mengatur alokasi waktu dalam menyajikan informasi karena tahapan ini terkadang melebihi batas waktu yang ditentukan.

3. Pada tahapan search out the meaning, siswa diberi kesempatan untuk menerapkan hasil pemahaman yang diperolehnya. Siswa dituntut lebih aktif dan kreatif dalam memaknai pembelajaran

mempermudah siswa sehingga menyelesaikan soal-soal yang berhubungan dengan materi pelajaran. Dalam pelaksanaannya tahapan ini dilakukan dengan bantuan kelompok. Dari hasil pengamatan, siswa aktif pada saat melakukan kegiatan kelompok. Hal ini karena siswa diminta untuk menyelesaikan tugas dengan bantuan alat-alat percobaan yang secara tidak langsung dapat membangkitkan ketertarikan dan keingintahuan mereka terhadap materi. Namun pada tahapan ini peneliti menemukan kendala seperti pengetahuan siswa bagaimana cara membaca dan memasang alat ukur listrik masih rendah sehingga banyak waktu yang terpakai untuk mengajarkan cara penggunaan alatalat ukur listrik tersebut. Untuk mengatasi hal ini, sebaiknya cara penggunaan dan pembacaan alat ukur listrik diberikan di luar jam pelajaran. Disamping itu, kebanyakan waktu terpakai untuk memeriksa rangkaian yang dibuat siswa apakah sudah benar, karena hal ini juga menyangkut keselamatan belajar siswa.

4. Tahapan trigger the memory melatih siswa untuk memanfaatkan kerja otak dalam menyimpan dan mengingat semua materi yang telah dipelajari. Tahapan ini sangat membantu siswa karena kemampuan ingatan akan memberikan manfaat bagi pembelajaran. Dari pengamatan peneliti, siswa terlihat berusaha mengingat dan mengulangi materi pada saat peneliti meminta mereka untuk mengerjakan soal di depan, menampilkan hasil percobaan dan merancang teknik donat.

5. Siswa diberi kesempatan untuk melatih dan menguji pemahamannya tentang materi yang telah dipelajari dengan mengerjakan soal-soal (kuis) yang diberikan peneliti dengan waktu yang telah ditentukan. Dari hasil tugas ini, peneliti dapat melihat sejauh mana pemahaman siswa dalam aspek kognitif.

6. Tahapan refleksi memberikan kesempatan bagi siswa dan peneliti untuk melihat sejauh mana kelebihan serta kekurangan dari kegiatan pembelajaran. Pada tahapan ini, siswa terlihat antusias dalam menyatakan pendapatnya sendiri. Namun pada tahapan ini peneliti menemukan kendala yaitu ada sebagian siswa yang tidak mengerti manfaat dari refleksi sehingga tidak semua siswa dapat mengeluarkan pendapatnya mengenai pembelajaran. Oleh karena itu, sebelum dilakukan guru harus menyampaikan maksud dan tujuan refleksi sehingga pendapat-pendapat siswa dapat mewakili hasil pembelajaran.

Berbeda halnya dengan model pembelajaran konvensional yang memandang siswa hanya sebagai objek belajar, sehingga suasana belajar menjadi monoton. Suasana belajar yang monoton mengakibatkan siswa menjadi jenuh dan konsentrasi siswa untuk mengikuti pelajaran akan terganggu sehingga banyak siswa yang tidak dapat memberikan respon ketika diminta untuk 
mengemukakan kembali informasi yang didapatkannya selama proses pembelajaran berlangsung. Disamping itu, model pembelajaran konvensional membuat siswa kurang kreatif karena siswa hanya terfokus pada mendengar dan mencatat saja sehingga kemungkinan kecil sulit bagi siswa memahami proses fisika itu sendiri.
Nicholl., Rose. (2002). Accelerated Learning for The $21^{\text {st }}$ Century. Alih bahasa Dedy Ahimsa. Bandung : Nuansa Cendekia

Slameto. (2003). Belajar dan FaktorFaktor yang Mempengaruhinya. Jakarta : Gramedia

\section{KESIMPULAN}

1. Rata-rata pretes kelas eksperimen sebelum diberi pembelajaran pada materi listrik dinamis adalah sebesar 40,26 dan setelah diberi perlakuan dengan menggunakan model MASTER diperoleh hasil belajar siswa sebesar 74,53. Hal ini menunjukkan adanya peningkatan hasil belajar siswa setelah diberi perlakuan dengan model MASTER

2. Model MASTER membangkitkan motivasi, ketertarikan dan keaktifan siswa dalam pembelajaran pada materi pokok listrik dinamis

3. Hasil pengujian hipotesis $t_{\text {hitung }}>t_{\text {tabel }}$ $(2,786>2,018)$ menunjukkan bahwa $\mathrm{H}_{\mathrm{a}}$ diterima yang berarti ada pengaruh konsep Accelerated Teaching model MASTER terhadap hasil belajar siswa pada materi pokok listrik dinamis di kelas X semester II MAN 2 Model Medan T.P. 2006/2007

\section{DAFTAR PUSTAKA}

Gunawan. (2004), Born To Be Genius. Jakarta : PT. Gramedia Pustaka Utama

\section{_ (2006). Genius Learning Strategy. Jakarta : PT. Gramedia Pustaka Utama}

Meier, Dave. (2005). The Accelerated Learning Handbook, Alih bahasa Rahmani Astuti. Bandung : Kaifa 